\title{
Review Article \\ Hypothyroidism and Thyroid Substitution: Historical Aspects
}

\author{
J. Lindholm and P. Laurberg \\ Department of Endocrinology, Aarhus University Hospital, 9000 Aalborg, Denmark \\ Correspondence should be addressed to J. Lindholm, j.lindholm@ofir.dk \\ Received 15 January 2011; Accepted 17 March 2011 \\ Academic Editor: Marian Ludgate
}

Copyright () $2011 \mathrm{~J}$. Lindholm and P. Laurberg. This is an open access article distributed under the Creative Commons Attribution License, which permits unrestricted use, distribution, and reproduction in any medium, provided the original work is properly cited.

\begin{abstract}
The last part of the 19th century was a period of great achievements in medicine and endocrinology. The thyroid gland evolved from being considered a rudimentary structure to an organ related to specific diseases. The singular importance of iodine became acknowledged. Graves-Basedow's disease was described. Surgical treatment evolved with extraordinary speed. Theodor Kocher observed that the clinical picture in patients after total thyroidectomy was similar to the one seen in cretinism. In 1850, the first case of hypothyroidism or myxedema was described. Less than 50 years later, effective treatment was introduced. Another 50 years later, autoimmune thyroiditis was ascertained as the most frequent cause of hypothyroidism (in areas with no iodine deficiency). This paper gives a short survey of the history of hypothyroidism and its treatment.
\end{abstract}

\section{Introduction}

During the 50 years preceding World War I, medicine saw a wealth of new ideas and novel procedures, not in the least within the field of endocrinology.

Among major achievements of this period were the recognition of the importance of the pituitary gland, first suggested by Oscar Minkowski (1858-1931) [1] and introduction of pituitary surgery [2] —not only for pituitary tumors but also as treatment of acromegaly [3]; the delineation of hypopituitarism as a nosological entity [4]; the discovery in 1877 (by a medical student) of the parathyroid glands [5] and recognition of their vital importance [6]; introduction of thyroid surgery, pioneered by Rehn [7], Theodor Billroth [8] and above all Theodor Kocher (1841-1917) [9]; Minkowski's demonstration that pancreatectomy swiftly leads to severe diabetes mellitus [10]. Halban [11] and Knauer [12] performed important experiments demonstrating that chemical substances controlling menstruations were released from the ovary. Similarly, Reinke [13] and Bouin and Ancel [14] proposed that testis was a gland with internal secretionstudies that were the vanguard of an impressive number of investigations on the relationship between the pituitary and the gonads [15]. The first hormone was synthesized (adrenaline or epinephrine) by Jokichi Takamine (18541922 ) in 1901 [16]. What was probably the supreme feat of the epoch took place on January 16, 1902 when William Bayliss (1860-1924) and Ernest Henry Starling (1866-1927) for the first time UK witnessed the effect of a substance later to be identified as a hormone (secretin) [17].

There was virtually no endocrine organ that did not become object of intensive investigation. It became clear that diseases of the thyroid gland affect a large number of patients.

In this paper, we briefly review how knowledge of the classical thyroid disease, then myxedema, now hypothyroidism, evolved.

\section{Early Observations on Myxedema}

In 1850 , a potentially important paper was published by Thomas Blizard Curling (1811-1888), surgeon at the London Hospital [18]. Two girls from an "idiot asylum" in Lancashire in England were described; in one-10 years of age— growth was severely stunted and "the countenance had a marked and very unpleasant idiotic expression (and she) had very little power of locomotion; but could manage to walk from chair to chair with a little assistance. She had no power of speech." 
There was no goiter. The other girl was 6 months of age and "was plump but had a marked idiotic expression, a large face with a small head, and very receding forehead. The tongue was large and protruding from the mouth".

Both died and autopsy was performed. No trace of the thyroid gland could be found. The author remarked: "I am not acquainted with any case on record in which a deficiency of the thyroid gland has been observed in the human body.... In countries where cretinism and bronchocele prevail, it was long supposed, that there was some connection between the defective condition of the brain, and the hypertrophy of the thyroid. Pathologists have recently been inclined to view the coincidence of these two affections as accidental, or as having no direct relation." At that time, the term "sporadic cretinism" was used while today the diagnosis would be congenital hypothyroidism. But the association between the clinical symptoms and the thyroid gland was not appreciated. The paper was overlooked and forgotten-not mentioned even in a British review [19].

Twenty years would pass till the publication of the next paper on this topic [20]. Fagge, assistant physician at Guy's Hospital, referred to a report of a 14-year-old boy from York County, England with obvious signs of cretinism and a large bronchocele. The author stated that "in reality, however, this case is the only one on record (so far as I can ascertain) in which cretinism has occurred sporadically, in association with goitre." He pointed out that he himself had seen patients that differed in as much as though they certainly presented with clinical evidence of cretinism, they had no goiter. His first patient, an 8-year-old boy, with "idiocy with stunting of body and cretinous type of face (?congenital); no goitre." The second patient was a girl characterized by "stunting of body, with change of features a cretinous type, dating from an attack of measles (?) at eight years of age; no goitre; soft tumours in both supraclavicular fosse; mental faculties unimpaired; age of patient nearly 17 years". The author concluded that "sporadic cretinism, instead of being associated (like endemic cretinism) with goitre, appears to be attended with a wasting or absence of the thyroid body". He also observed that in children stunted growth was typical in "sporadic cretinism" and that "it springs up, generally without apparent cause, in the offspring of a healthy father and mother". Finally, he noticed that the cause of sporadic cretinism had attracted very little attention (though "it has been supposed in certain cases to have resulted from one or both of the parents having been intoxicated at the time of procreation"!).

Curling and Fagge were among the very last physicians to use the medieval expression bronchocele for goiter.

Practically every textbook states that Wiliam Gull, Governor of Guy's Hospital and Physician-in-Ordinary to Queen Victoria, was the first to describe myxedema as he in 1874 described what he called a "cretinous state in the adult" [21]. His paper is brief, not very informative and the thyroid gland is hardly mentioned except the remark, "In the cretinoid condition in adults which I have seen, the thyroid was not enlarged." Gull expressed his somewhat hazy views on the disease "I believe it to be a rare form of constitutional disorder, without any internal visceral disease, but characterised by great inaptitude to spontaneous exertion both of mind and body. The deposit of fat and the changes in the skin and connective tissues correspond to a languid condition of the venous circulation, but without any tendency to oedema, or any sign of cardiac defect". It is beyond human imagination how this paper can be constructed as the first description of myxedema. However, Gull had the presence of mind to note "the state is a substantive and definitive one, no one will doubt who has had fair opportunity of observing it".

In 1878 Ord from St. Thomas Hospital [22] published a paper in which he coined the term myxoedema and published the first photography of a patient (Figure 1). He was able to confirm the findings of Curling "the thyroid was reduced to about a fourth of its natural size, and, being flattened against the larynx, was hardly felt during life. Its normal structure was almost entirely wanting, being replaced by myxoedematous infiltration. The absence of a thyroid gland in cases of cretinoid idiocy is certainly curious, goitre being very abundant in regions where cretinism is endemic." He gave myxoedema its name from the "jelly-like swelling of the connective tissue. the cut surfaces yielded less fluid than their appearance would promise". He made further reflections in another paper in 1878 [23].

In all these papers cretinism, cretin, and cretinous were the key words. None of the authors was aware of the fundamental causal importance of the thyroid gland.

\section{Theodor Kocher and Victor Horsley}

At a meeting in Berlin in April 1883, Professor Theodor Kocher of Berne read a paper on the extirpation of the thyroid [9]. He had become aware of a peculiar postoperative course in one of his patients. This led him to call in for followup as many as possible of the 101 patients on whom he had performed thyroid surgery (at that time a phenomenal number). He immediately saw how the course significantly differed between patients who had undergone partial and patients after total thyroidectomy. He made the conclusion that the symptoms present in patients in whom he had removed the entire thyroid were unmistakably similar to those found in patients with cretinism.

On November 23, 1883 in the Clinical Society of London, Dr. Dawtrey Drewitt presented a patient with classical symptoms of hypothyroidism [24]. Somebody in the audience remarked "that there appeared to be three conditions closely allied to each other, and having in common either absence or probably complete degeneration of the thyroid body: namely, cretinism, myxoedema, and the state after total removal of the thyroid body". At the same meeting, the first case of painless thyroiditis in pregnancy was briefly described.

Sir Victor Horsley (1859-1916) (Figure 2) was another outstanding figure in the field of medicine in the last half of the 19th century-involved in many areas of medicine and physiology [25]. He is most renowned as a neurosurgeon (the first to perform pituitary surgery) [26].

Horsley reviewed the possible function of the thyroid gland [27]: "Up till the year 1883, the function of the thyroid 

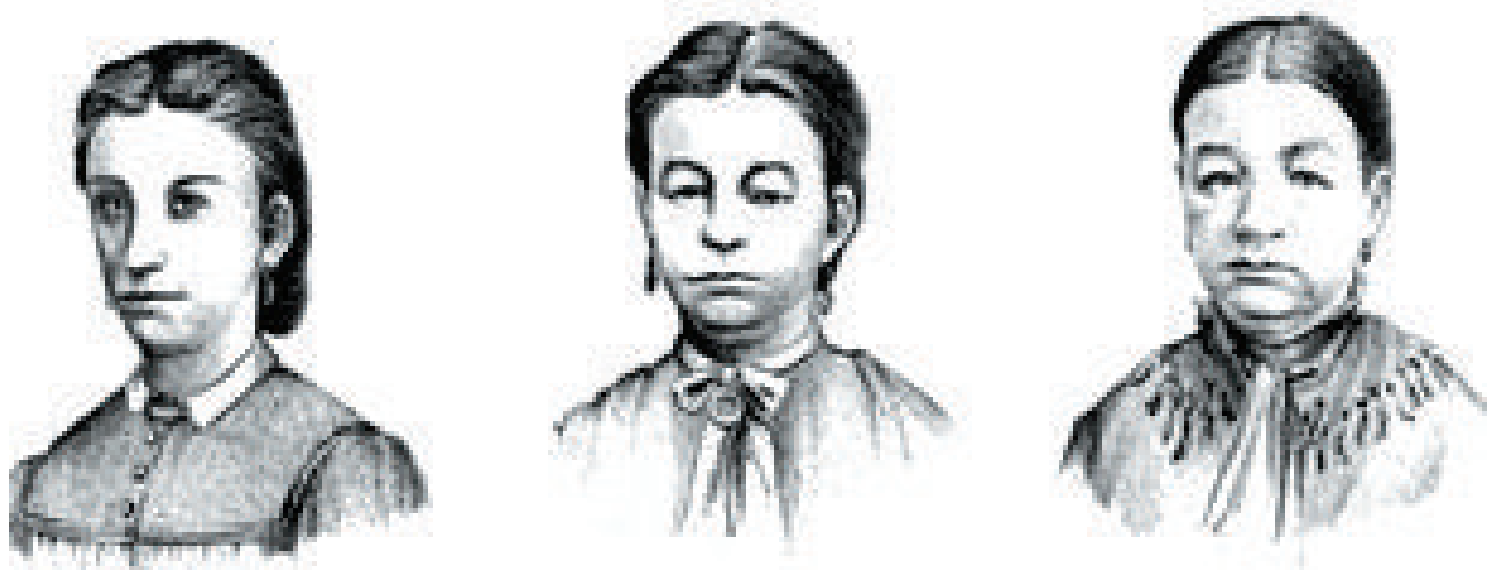

FIGURE 1: First photo of a patient with myxedema. From Ord (1878). (a) Patient at the age of 21-before onset of symptoms. (b) Seven years later. (c) Four years later.

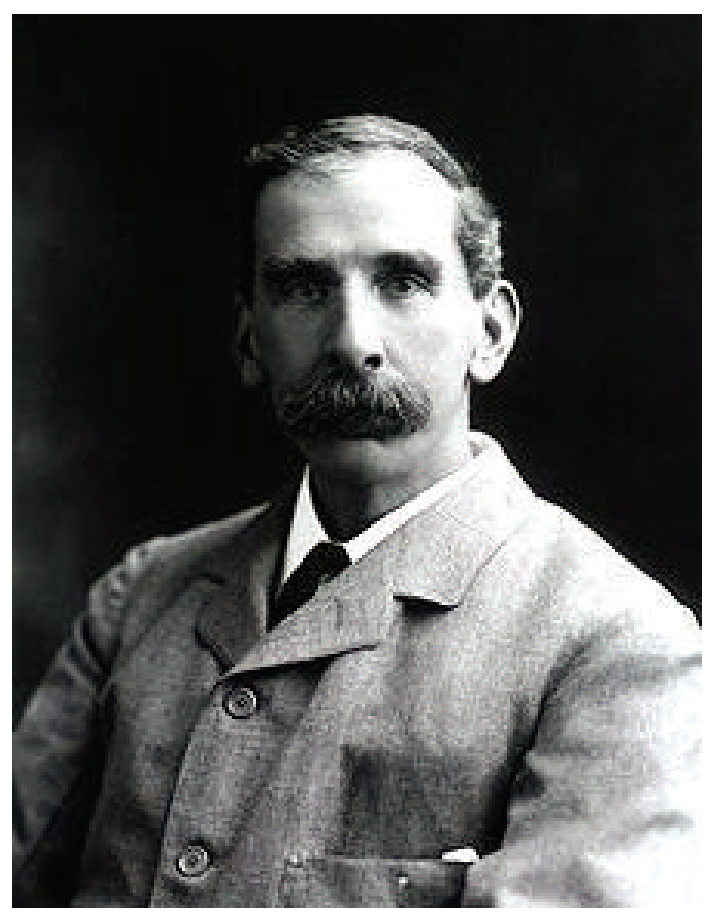

FIgURE 2: Sir William Horsley (1859-1916).

gland was unknown, and considered to be of slight importance, at least to the adult animal. The theories concerning its function were: (1) The one propounded by Mr. Simon (in) 1844, that the thyroid body acted as a regulator of the circulation in the brain, and possibly manufactured some substance which was of primary importance for the nutrition of the central nervous system. (2) That it was a true gland, and secreted a mucinous albuminoid into the cavities of its acini, the secretion being reabsorbed by the lymphatics. (3) The thyroid gland has also from time to time been compared to the spleen as a hematopoietic organ”.
He gave an account of his experience of removing the thyroid in animals. He was in no doubt that when he excised the thyroid, myxedema gradually developed. Horsley speculated "the practical surgical question (is) as to whether the cretinous symptoms following thyroidectomy are due to (1) Chronic asphyxia, as believed by Kocher; (2) Injury of the sympathetic and other nerve trunks (3) Arrest of function of the thyroid gland is almost settled in favour of the third view, and with it also the pathology of Myxoedema." Horsley described in detail tetany but of course could have no idea of its cause.

In The British Medical Journal in 1885, he summed up recent research within this field [28]. He began by stating "various as have been surmises as to the function of the thyroid gland, it is not a little surprising that, although arrest of it had been vaguely known for hundreds of years to be connected with the cretinous state.... Cretinism, as is well known, has been attributed to every cause except the destruction of the thyroid. Chalky water, damp close air, miasma, insufficient food, and so forth, and hereditary influence, have all been credited with the power of causing the imbecile condition which is so familiar to everyone."

He went on stating "I am prepared, in my first two lectures, to support the dictum (first completely enunciated by my friend, Dr. Felix Semon) that cretinism, congenital or acquired myxoedema, and cachexia strumipriva, are merely phases of one and the same state, and due to the same cause, namely, arrest of the function of the thyroid gland." Horsley's reference to Felix Semon (1849-1921) is a little odd. It is true that in the above meeting of the Clinical Society in London 1883, it was just Semon who had in fact made this suggestion.

However, he clearly stated that he was citing Kocher who shortly before had presented his hallmark study on thyroidectomy and its consequences [9]. Felix Semon was present at this meeting - not surprising as he in fact was a Prussian who had moved to Great Britain where he was one of the founders of otolaryngology-having special interest in cancer of the larynx and not in thyroid diseases. 


\section{Cretinism, Endemic Goiter, Iodine, and Hypothyroidism}

Though there is no complete agreement on the definition, it is fair to say that at present cretinism denotes the extreme clinical picture secondary to lack of thyroid hormone during critical phases of development. When the condition is sporadic, it is typically caused by thyroid gland agenesis or dysgenesis or defective biosynthesis of thyroid hormone. Endemic cretinism occurs in areas where severe iodine deficiency is present. Such areas would characteristically also be affected by endemic goitre.

Authors in ancient Rome made reference to the common occurrence of goiter in the Alps. Cranefield, in his excellent review [29], cites Vitruvius (c 75-c 10 BC) for the statement "the Acquiculi in Italy and the nation of the Medulli in the Alps have a kind of water which causes those who drink it to have swollen throats" and Juvenal (late 1st century AD) for "who wonders at a swollen throat in the Alps?" Curiously, no text mentioning the neurological symptoms or mental deficits is on record.

The earliest recognition of the association between goiter and intellectual impairment typical of cretinism may be an illustration in a book "Reuner Musterbuch" written in 1215 at a Cistercian Abbey near Graz in present-day Austria. It depicts an obviously imbecile person with a monstrous goiter. Merke [30] found several descriptions of the occurrence of goiter in the Pyrenees and Alps in the literature from between 1300 and 1418, but oddly idiocy was not mentioned here either.

Theophrastus Bombast von Hohenheim, better known as Paracelsus (1493-1541), is often referred to as the first to describe the combination of goiter and cerebral and intellectual deficiencies in 1527 [31]. However, his description is lapidary in the extreme ("the strumeous are rarely intelligent”). According to Cranefield [29], a Swiss physician Felix Platter (1536-1614) gave the first more detailed description of cretinism in 1602: "it is usual that many infants suffer from innate folly. Besides, the head is sometimes misshapen: the tongue is huge and swollen; they are dumb; the throat is often goitrous. Thus they present an ugly sight; and sitting in the streets and looking into the sun, and putting little sticks in between their fingers, twisting their bodies in various ways, with their mouths agape they provoke passersby to laughter and astonishment."

The term "cretinism" appears first in the French dictionary (encyclopédie) published by Diderot in 1754. The origin of the word cretin has been much debated-it has been speculated that the word "cretin" developed from the SwissFrench word crestin meaning Christian or human being, as a reminder that these imbecile, disfigured, and grotesque creatures were humans and not beasts.

After the discovery of iodine in 1811, it was soon speculated that iodine might have a prophylactic effect on goiter. Coindet, a physician from Geneva, began dispensing iodine tincture to patients with goiter, though he had no idea of the mechanism [32]. Boussingault, a French mining engineer (1802-1887), traveled extensively in South America and noticed the huge number of subjects with goiter (and cretinism)_- "the most deplorable condition seen in mankind". His main thesis was that goiter was instigated by lack of oxygen in drinking water. It was common at the high altitudes in mountains because of reduced atmospheric pressure. He was, however, aware of one substance which was infallible in treating goiter: iodine. He observed that goiter was absent in areas where drinking water was rich in iodine and frequent when water was iodine depleted. He also noted that people who settled in an iodine-poor area would develop goiter which disappeared when traveling to an iodine rich region. He advocated the use of iodinated salt [33]. His paper, published in 1833, is very impressive, based on traveling in a vast area including modern Columbia and Venezuelamaking stringent observations within chemistry, geology, and medicine.

The French chemist Adolphe Chatin (1813-1901) was the first to propose that goiter might be caused by iodine deficiency. He remarked "the main cause of goiter seems to be a low concentration of iodine in the drinking water in certain areas. Changing the water source and animal foods and above all of eggs are rational treatments against this condition" [34]. The German chemist Baumann cheerfully commented on these words, "they were consigned to eternal oblivion".

In the 1860s, the first trials had been conducted in three regions of France (Departements de Bas-Rhin, Seine-Inferieure, and Haute-Savoie) [35]. The administration of iodine yielded promising results. 5000 children with goiter were given iodine and 4000 were cured or "showed marked improvement”.

\section{Clinical Presentation}

Even at an early time, the clinical presentation of myxedema was well known. In the UK alone, a fair number of papers dealt with myxedema in the 1870 s and 1880s — some have been reviewed by Doyle [19]. Many of these case reports still make fascinating reading.

Before treatment became routine, hypothyroidism frequently ran a fatal course-10 years being the typical length of time from diagnosis to demise. It is apparent that the hypothyroid patient seen by physicians often would appear quite different from the one seen today. Many patients were not diagnosed until late in the course when severe intellectual, neurological, and psychiatric deficiency had left the patient in an extreme calamitous situation with dementia, debilitating neuropathy including speaking and hearing deficits and hypothermia-symptoms seen only exceptionally rarely today. In one patient in whom hypothyroidism apparently had precipitated psychosis with religious delusions, body temperature had fallen to $24.5^{\circ} \mathrm{C}$ !

In 1989, Fulop [36] called attention to what he considered an often overlooked finding in one of his hypothyroid patients: enlarged salivary glands. He referred to an old Czechoslovakian paper which he thought was the first study 
to mention this phenomenon. However, several early publications, the first one seems to be Horsley's lecture in 1885 [28], pointed out that enlarged salivary glands are (or at least at that time) were a characteristic and not infrequent finding in myxedema.

\section{Causes of Hypothyroidism}

So, at the end of the 19th century it was generally assumed that hypothyroidism was brought about by hyposecretion in the thyroid of one or more substances. A study in 1895 by Baumann in Germany (the same Baumann who had conveyed such sanguine views on Chatin's hypothesis on iodine) was highly important [37]. He found a substance (thyroiodine) rich in iodine in thyroid tissue in both animals and man, effective in treating myxedema. This finding suggested that iodine somehow was crucial for thyroid function. This made it easy to understand why iodine deficiency might lead to hypothyroidism.

In 1912, a completely novel concept was introduced: struma lymphomatosa, a thyroiditis, which for years mainly was an anatomical designation, based on the presence of lymphocytic infiltrates in the thyroid gland [38]. Within the following years, German investigators published accounts on this disorder [39] but it attracted slight interest.

It was recognized that autoantibodies were central in causing Graves-Basedow's disease [40]. About the same time, it was suggested that thyroid antibodies might also be involved in the development of hypothyroidism [41, 42]. Not only thyroiditis but also disorders such as diabetes mellitus type 1 and Addison's disease would prove to be autoimmunological disorders.

While many details of the immunological response remain to be sorted out, there is convincing evidence that to a large extent it is controlled by genetic factors [43]. The role of exogenous issues-for example, iodine intake [44] and smoking $[45,46]$ - has not been settled and appears complex. Presence of lymphocytic infiltrates correlates with the amount of circulating thyroid antibodies [47].

At present, the term thyroiditis has been used for a century and the pertinent literature is exorbitant. Nevertheless, there is still confusion how it should be defined and subdivided. For example many use the term autoimmune thyroiditis to cover both primary myxedema without goiter and Hashimoto's goiter while others suggest they are distinct diseases. It is known that some antibodies are cytotoxic and some block the effect of thyrotropin, but exactly how these antibodies precipitate hypothyroidism has not been settled.

Davies and Amino recently proposed a simple classification: type 1 and type 2 to cover the different presentations of what many call Hashimoto's thyroiditis while type 3 includes Graves-Basedow's disease [48]. Subtypes indicate whether hyper-, hypo- or euthyroidism is present.

Until recently hypothyroidism was worldwide most often caused by iodine deficiency [49]. Considering the many programs initiated where food supplies are fortified with iodine, today autoimmune thyroid disease might (and certainly ought to) be the most frequent cause of hypothyroidism.
Recent reviews have summarized the various causes of congenital and acquired hypothyroidism [50,51].

\section{Relationship between Cretinism and Myxedema}

For more than a century, distinction has been made between a neurological "nervous" and a myxedematous type of cretinism [52]. Mixed (or intermediate) forms are encountered. The distribution of the forms varies according to the endemic area. Obviously, iodine deficiency is a key factor in both types. Whereas the myxedematous type as the name implies is clinically associated with hypothyroidism (including stunted growth and sexual immaturity), patients with the neurological type are often euthyroid (though frequently with goiter). Iodine given before or early in the pregnancy will prevent the development of neurological cretinism [53]. In an important study [54] from Congo, Vanderpas and coworkers showed that in the myxedematous type of cretinism treatment with iodine will normalize thyroid function-provided treatment is begun early in the postnatal period. If not, the prognosis remains dismal.

It has puzzled researches how iodide deficiency of similar magnitude may lead to such clinical diversity. In a careful and well-argued analysis of published data and their own recent findings, Boyages and Halpern have suggested that two events are involved in endemic cretinism [55]. One is a transient thyroxine deficit transmitted from mother to fetus around the time of the midtrimester with neurological and intellectual consequences. This event occurs in all cretins whereas the second (postnatal) period of thyroid hormone deficit takes place in a subgroup only. It is the length and severity of this second event that will decide the extent of clinical hypothyroid symptoms present.

Though the exact cause of myxedematous cretinism is still unclear, a wealth of skillful research has demonstrated the importance of iodine. It is one of medicine's major mysteries, why it took so long for this simple message to be transformed into straightforward measures ensuring that populations in exposed areas are provided with iodine.

Zimmermann has recently published a superb review of the early iodine prophylaxis [56].

\section{Thyroid Hormones and Therapy of Hypothyroidism}

In a detailed report (215 pages) delivered in 1888 by a committee set up by the Clinical Society in London on the relationship between cretinism, myxedema, and struma thyropriva, the clinical symptoms are described in detail but treatment is hardly mentioned [57].

However, a few other investigators were toiling with the possibility of therapy and clarifying thyroid function. Thus, the eminent German physician and physiologist Moritz Schiff (1823-1896) while working in Berne performed important experiments. He reported "thyroidectomy loses its danger, and an essential amount of its effect, if one previously introduces and fixes in the abdominal cavity other 
thyroid glands from an animal of the same species" [58]. Similar grafting was performed by von Eiselberg who at the same time transplanted thyroid and parathyroid tissue and thus became the first to perform parathyroid grafting [59], though obviously he was unaware of the function of parathyroid glands. They were discovered in 1877 [5], but it would last almost until the end of the century before their function was recognized [60]. Postoperative tetany (sometimes called "acute myxedema") was believed to reflect injury to the thyroid gland. Thyroid transplantation in man was soon taken up by Bettencourt and Serrano in Lisbon [61]. The effect was remarkably swift and-in fact, so swift that the authors wisely suggested that it might be due to the absorption of the juice from healthy thyroid gland by the tissues of the patient.

In a letter in June 1891 [62], Horsley informed George Redmayne Murray (1865-1939) about the progress made in various European countries as to finding treatment for hypothyroidism. Murray at that time was a pathologist at the Hospital for Sick Children in Newcastle. A few months later, Murray published the first account of a human patient with hypothyroidism given substitution with thyroid extract (injected subcutaneously) [63]. Clinically, the effect was beyond doubt. The patient lived almost 30 years on thyroid substitution-eventually to die of cardiac failure in 1919 [64].

Within months, it was discovered that oral administration of thyroid extract was effective [65-67]. Fenwick [68] noted a marked increase in diuresis after commencement of thyroid substitution therapy.

It is evident that Murray's achievement was not a sudden lightning of an ingenious mind but rested on studies by a number of investigators suggesting that the thyroid contained a substance of benefit in myxedema. In particular, the contributions by Schiff and Eiselberg were fundamental-as were of cause the experiments by Murray's mentor, Horsley.

Naturally, the central question as far as thyroid extract was concerned, was which substance was responsible. Important clues were Baumann's study in 1895 and the finding in 1907 by Marine [69] that iodine was necessary for proper function of the thyroid gland. Magnus-Levy demonstrated the important fact that desiccated thyroid and iodothyrin increase oxygen consumption and output of carbon dioxide [70].

A vivid description has been given of what a physician might encounter at that time [71]. Around 1892, an Irish general practitioner was asked to see a lady who obviously was dying, her family being aware no treatment was possible. The diagnosis was clinically obvious. The GP had just read in the British Medical Journal about the proposed treatment of myxedema and straight away got hold of thyroid glands from sheep. Following the instructions in the papers, he prepared a substance which was administered to the patient who stunned everybody by a swift and complete, almost biblical, recovery. Incidentally, the physician later gained further fame by operating on an old and destitute woman on his kitchen table, curing her cataract.

In 1896, Murray-not without a little pride-summed up the present state of treatment of hypothyroidism [72].
He affirmed "myxedema is a symptom or combination of symptoms of loss of the function of the thyroid gland. In the idiopathic form it is a symptom of chronic interstitial thyroiditis, just as anasarca may be a symptom of renal disease or ascites of hepatic disease. Thus the myxedema can be cured, although the chronic interstitial thyroiditis still remains." This statement, regarding a disease that only a few years before often was fatal and the cause of which 10 years previously remained nebulous, is certainly testimony of an exceptionally dynamic period in medical science.

In 1914 on Christmas day, at the Mayo Clinic, Edward Calvin Kendall (1886-1972) crystallized a substance-later to be named thyroxine-containing $65.3 \%$ iodine [73]. When he repeated the procedure, he failed to isolate any crystals. It would take 15 frustrating months finally to get the procedure right. Eventually, $33 \mathrm{~g}$ of crystalline substance was obtained [74]. This allowed studies on its physiological properties.

Perhaps because of the war, thyroxine was not chemically identified until 1927 [75]. About 25 years later, Gross and Pitt-Rivers [76] detected the second thyroid hormone- -triiodothyronine, which at the same time also was demonstrated by French investigators [77, 78].

Almost as if they were introducing a completely new drug, Hart and Maclagan in 1950 [79] reviewed the use of thyroxine (and particularly L-thyroxine). Actually, it had been available since the 1930s but had not gained wide acceptance (maybe because of its high cost) - despite its obvious advantages. Desiccated thyroid was much used for many years and as late as 1978 leading British endocrinologists felt compelled to warn against its use [80]. It is still being marketed (and hence probably used) in some countries-for example, USA.

\section{Organotherapy}

Modern medicine developed the concept of organotherapy in the latter part of the 19th century-advanced in particular by an extraordinary figure: Charles-Edouard Brown-Séquard (1817-1894) [81]. He had advocated the use of extracts from ovaries and testes-many of his theses were based on excellent results in experiments he had performed on himself $[82,83]$. In some respects, his theories would lead medicine into an abyss of eeriness and utter bewilderment, but in other instances it would precipitate important progress in endocrine therapy. There can be little doubt that the benefit of thyroid substitution was a major support for the soundness of organotherapy. A veritable industry grew up and extracts from a variety of organs including brain and spinal cord were marketed and widely used (Figures 3(a)-3(c)).

Organotherapy could claim some other successes. Around 1890 Vassale in Italy [84] and Gley [85] in France had injected thyroidectomized dogs with extract of thyroid glands from sheep. There was an excellent effect on postoperative tetany (which they ascribed to thyroid insufficiency). 1908 McCallum effectively treated postoperative tetany with an extract known to be of parathyroid origin [86]. In 1913, two reports, one from Germany [87] and one from Italy 
PROFESSOR

\section{BROWN SEQUARD'S}

METHOD.

\section{EXTRACTS OF ANIMAL ORGANS.}

Testicle Extract.

Grey Matter Extract.

Thyroid Cland Extract, \&c., \&c. Concentrated Solutions at $30 \%$.

These preparations, completely aseptic, are mailed to any distance on receipt of a money order. Directions sent with the fluids.

Price for 25 Injections, $\$ 2.50$

Syringe Specially Gauged, ( 3 cubic c., $\$ 2.50$.

Used in the Hospitals of Paris, Neat York, Boston, che

Circular Sent on Application.

New York Biological and Vaccinal Institute,

Laboratory of Bovine Vaceine and of Biological Prodnets.

GEO G. RAMBAUD, Chemist and Bacteriologist, Supcrintenden.

PASTEUR INSTITUTE BUILDING, NEW YORK CITY.
ADVERTISENENTS.

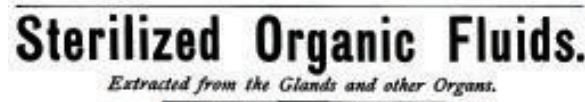

Messry. FERRIS \& COMPANY, Union Street, Bristol, beg to announce that they hare bees appointed SOLE AGENTS

ORGANIC FLUIDS

Prepared by Messrs. CHAIX \& REMY, Paris,

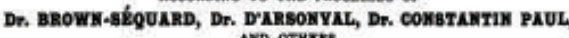

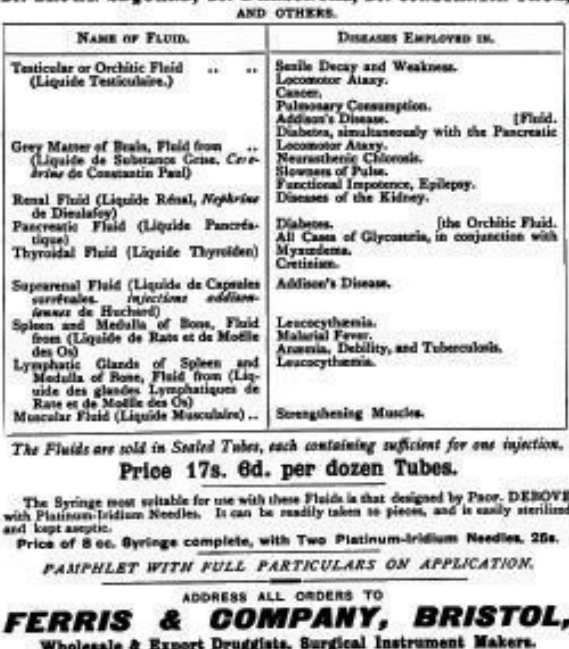

(a)

(b)

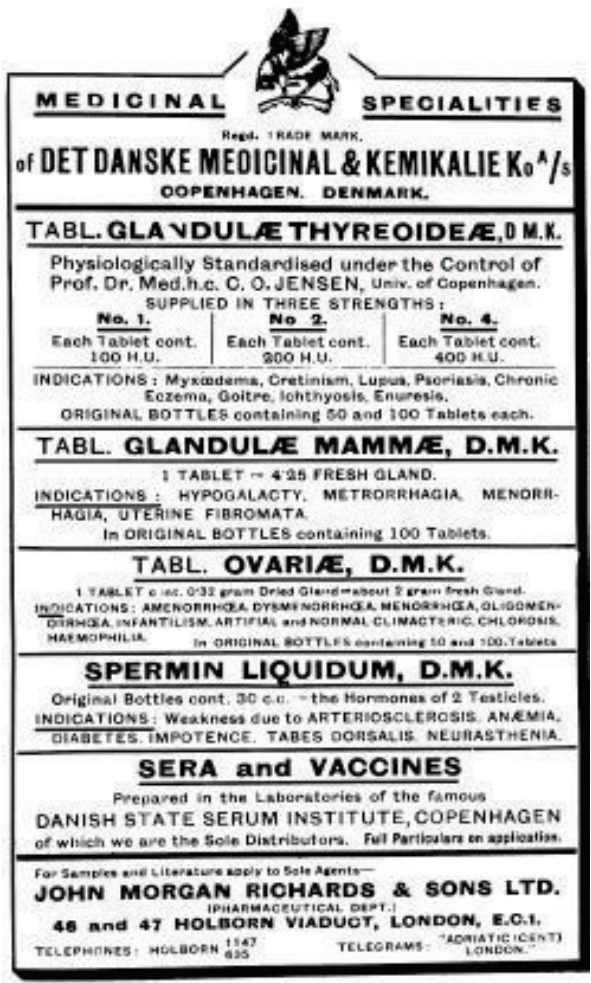

(c)

Figure 3: Advertisements for organotherapeutical remedies. 
[88], demonstrated the swift and unquestionable effect of extract of the posterior lobe of the hypophysis on polyuria in diabetes insipidus.

Only few years after Minkowski's demonstration of the association between pancreatectomy and diabetes mellitus, organotherapy was also introduced as therapy for diabetes mellitus [89]. Patients were made devour a whole pancreatic gland per day. The results, however, were dismal. Pancreatic transplantation was attempted, first in 1893 [90], but proved an utter disaster.

As an illustration of the belief in organotherapy (though not necessarily involving the thyroid), an interesting piece of evidence is provided by a short novel (The Creeping Man) [91] written by Sir Conan Doyle (1859-1930)_ a physician by education. Briefly, the story deals with a professor who at a somewhat advanced age plans to marry a much younger (and pretty) woman. To some consternation of his family members and associates, his behavior undergoes a distinct change. He starts to climb walls, walk on all four and in general behave like an animal. His faithful dog begins to attack him. Sherlock Holmes solves the puzzle by demonstrating that the professor had begun treating himself with extract from (testicular?) tissue from monkeys. Today, this plot will appear queer, almost meaningless.

Tam [92] has given an excellent account of thyroid organotherapy in Britain. Desiccated thyroid was prescribed for a large number of ailments - thus obesity, various skin diseases, asthma, and an array of gynecological diseases "the stimulating action of the thyroid on the ovaries has been used to good advantage in the treatment of ovarian insufficiency with its various manifestations - for example, infantilism, amenorrhea, scanty menstruation, sterility.... It is not possible to explain the broad influence of thyroid medication upon this class of disease: it is far too complex", and curious and ill-defined conditions called "toxemias." As late as just before World War II, a book (Walker G. The status of enzymes and hormones in therapy. Edinburgh, John Wright \& Sons Ltd., 1935) was published reviewing the numerous indications for organotherapy. It concluded "thyroid is indicated in any condition in which there is depressed metabolism, and hence its range of utility extends from anorexia nervosa to ulcers of the leg." The whole organotherapy circus would go on until Word War II when finally this appalling chapter of the medical profession finally would be brought to a stop [15].

\section{Conclusion}

Careful study of the history of hypothyroidism reveals that investigators not widely known have in fact played a crucial role in the development of our knowledge of thyroid insufficiency. Thus, today probably only few are acquainted with Felix Platter who gave the first description of cretinism, with Curling who described patients with myxedema in 1850, and perhaps even with Chatin who was the first to suggest the significance of iodine in thyroid pathology. On the other hand, the immense importance of Kocher and Horsley in the last half of the 19th century is well known.
At this time, Murray successfully introduced treatment with thyroid extract in hypothyroidism. In France, an apparently adequate prophylaxis for one of mankind's major scourges; cretinism was launched at an early time. This policy was soon discontinued. The reason why this practice was terminated is not entirely clear. As early as around 1820 Coindet and Magendie had noted that the administration of iodine might cause symptoms of hyperthyroidism (Kocher's "Jod-Basedow"). For more than a century, the safety of iodine prophylaxis was heatedly discussed until it was realized that the purpose of iodine prophylaxis ideally should be to ensure a sufficient iodine intake [93]. Problems would appear if iodine was given in supraphysiological amounts [94].

So within less than 50 years, hypothyroidism was recognized, and effective treatment was made available. Prevention of the most frequent type of hypothyroidism was documented, and preventive intervention had in fact been instituted. However, partly because the medical establishment and health authorities showed little concern, early initiatives were abandoned causing much misery to generations in large parts of the world.

\section{Conflict of Interests}

The authors declare that no competing financial interests exist.

\section{Acknowledgments}

The authors are thankful to Mr. Jakob Borg Andersen, Medical Library, Aarhus University Hospital, Aalborg for his competent and efficient assistance.

\section{References}

[1] O. Minkowski, "Ueber einen Fall von Akromegalie," Berliner Klinische Wochenschrift, vol. 24, pp. 371-374, 1887.

[2] H. Schloffer, "Erfolgreiche operation eines hypophysentumors auf nasalem wege," Wiener Klinische Wochenschrift, vol. 20, pp. 621-624, 1907.

[3] E. Stumme, "Akromegalie und Hypophyse," Archiv fur Klinische Chirurgie, vol. 87, pp. 437-466, 1908.

[4] M. Simmond, "Über hypophysisschwund mit tödlichem ausgang," Deutsche Medizinische Wochenschrift, vol. 40, pp. 322323, 1914.

[5] C. M. Seipel, “An English translation of Sandstrom's 'glandulae parathyroideae," Bulletin of the History of Medicine, vol. 6, pp. 179-222, 1938, (originally published in Swedish: Upsala Läkareförenings Förhandlingar 1879-1880; 15: 441-471).

[6] E. Gley, "Sur les fonctions du corps thyroide," Comptes Rendus des Seances de la Societe de Biologie et de ses Filiales, vol. 43, pp. 841-842, 1891.

[7] L. Rehn, "Über die Exstirpation des Kropfs bei Morbus Basedowii," Berliner Klinische Wochenschrift, vol. 21, pp. 163$166,1884$.

[8] A. Wölfler, "Die Kropfextirpationen an Hofr. Billroth's Klinik von 1877 bis 1881," Wiener Medizinische Wochenschrift, vol. 32, pp. 5-7, 1882.

[9] T. Kocher, "Ueber Kropf exstirpation und ihre Folgen," Archiv fur Klinische Chirurgie, vol. 29, pp. 254-335, 1883. 
[10] J. V. von Mering and O. Minkowski, "Diabetes mellitus nach Pankreasexstirpation," Archiv für Experimentelle Pathologie und Pharmakologie, vol. 26, no. 5-6, pp. 371-387, 1890.

[11] J. Halban, "Ueber den Einfluss der Ovarien auf die Entwicklung des Genitales," Monatsschrift für Geburtshilfe und Gynäekologie, vol. 12, pp. 496-505, 1900.

[12] E. Knauer, "Die Ovarientransplantation. Experimentelle Studie," Archiv fur Gynäkologie, vol. 60, no. 2, pp. 322-376, 1900.

[13] F. Reinke, "Beiträge zur histologie des menschen. I. Ueber krystalloidbildungen in den interstitiellen zellen des menschlichen hodens," Archiv fur Mikroskopische Anatomie, vol. 47, pp. 34-44, 1896.

[14] P. Bouin and P. Ancel, "Recherches sur les cellules interstielles du testicule des mammifères," Archives de Zoologie Expérimentale et Générale, vol. 1 (4. serie), pp. 437-523, 1903.

[15] J. Lindholm and E. H. Nielsen, "Pituitary-gonadal axis: historical notes," Pituitary, vol. 12, no. 3, pp. 226-235, 2009.

[16] J. Takamine, "The isolation of the active principle of the suprarenal gland," Journal of Physiology, vol. 27, pp. 29-30, 1901.

[17] W. M. Bayliss and E. H. Starling, "The mechanism of pancreatic secretion," Journal of Physiology, vol. 28, pp. 325-353, 1902.

[18] T. B. Curling, "Two cases of absence of the thyroid body, and symmetrical swellings of fat tissue at the sides of the neck, connected with defective cerebral development," MedicoChirurgical Transactions, vol. 33, pp. 303-306, 1850.

[19] L. Doyle, "Myxoedema: some early reports and contributions by British authors, 1873-1898," Journal of the Royal Society of Medicine, vol. 84, no. 2, pp. 103-106, 1991.

[20] C. H. Fagge, "On sporadic cretinism, occurring in England," Medico-Chirurgical Transactions, vol. 54, pp. 155-169, 1871.

[21] W. W. Gull, "On a cretinoid state supervening in adult life in women," Transactions of the Clinical Society of London, vol. 7, pp. 180-185, 1874.

[22] W. M. Ord, "On myxoedema, a term proposed to be applied to an essential condition in the 'cretinoid' affection occasionally observed in middle-aged women," Medico-Chirurgical Transactions, vol. 61, pp. 57-74, 1878.

[23] W. Ord, "Clinical lecture on myxoedema," British Medical Journal, vol. 1, pp. 671-672, 1878.

[24] "Reports of Societies. Clinical Society of London," British Medical Journal, vol. 2, pp. 1072-1074, 1883.

[25] A. MacNalty, "Sir Victor Horsley: his life and work," British Medical Journal, vol. 1, no. 5024, pp. 910-916, 1957.

[26] J. Lindholm, "A century of pituitary surgery: Schloffer's legacy," Neurosurgery, vol. 61, no. 4, pp. 865-867, 2007.

[27] V. Horsley, "On the function of the thyroid gland," Proceedings of the Royal Society of London, vol. 38, pp. 5-7, 1885.

[28] V. Horsley, "The Brown Lectures on Pathology. The thyroid gland: its relation to the pathology of myxoedema and cretinism, to the question of the surgical treatment of goitre, and to the general nutrition of the body," British Medical Journal, vol. 1, pp. 111-115, 1885.

[29] P. F. Cranefield, "The discovery of cretinism," Bulletin of the History of Medicine, vol. 36, pp. 489-500, 1962.

[30] F. Merke, "The history of endemic goitre and cretinism in the thirteenth to fifteenth centuries," Proceedings of the Royal Society of Medicine, vol. 53, pp. 995-1002, 1960.

[31] P. Cranefield and W. Federn, "Paracelsus on goiter and cretinism: a translation and discussion of 'de struma, vulgo der Kropf'," Bulletin of the History of Medicine, vol. 37, pp. 463471, 1963.

[32] J. F. Coindet, "Decouverte d'un nouveau remède contre le goitre," Annals of Clinical Psychiatry, vol. 15, pp. 49-59, 1820.
[33] J. B. Boussingault, "Recherches sur la cause qui produit le goitre dans les Cordilieres de la Nouvelle-Grenade," Annales de Chimie et de Physique, vol. 48, pp. 41-69, 1833.

[34] A. Chatin, "Recherches sur l'iode des eaux douces; de la présence de ce corps dans les plantes at les animaux terrestes," Comptes Rendus Hebdomadaires des Séances de l'Academie des Sciences, vol. 31, pp. 280-283, 1851.

[35] "Leading article. Goitre in Savoy," The Lancet, vol. 94, p. 518, 1869.

[36] M. Fulop, "Pouting sublinguals: enlarged salivary glands in myxoedema," The Lancet, vol. 334, pp. 550-551, 1989.

[37] E. Baumann, "Ueber das normale Vorkommen von Jod im Thierkörper," Hoppe-Seyler's Zeitschrift fur Physiologische Chemie, vol. 21, pp. 319-330, 1895.

[38] H. Hashimoto, "Zur Kenntnis der lymphomatoser Veränderung der Schildruse (struma lymphomatosa)," Archiv fur Klinische Chirurgie, vol. 97, pp. 219-224, 1912.

[39] H. E. Takami, R. Miyabe, and K. Kameyama, "Hashimoto's thyroiditis," World Journal of Surgery, vol. 32, no. 5, pp. 688692, 2008.

[40] J. Lindholm and P. Laurberg, "Hyperthyroidism, exophthalmos, and goiter: historical notes on the orbitopathy," Thyroid, vol. 20, no. 3, pp. 291-300, 2010.

[41] I. M. Roitt, P. N. Campbell, and D. Doniach, "The nature of the thyroid auto-antibodies present in patients with Hashimoto's thyroiditis (lymphadenoid goitre)," Biochemical journal, vol. 69, no. 2, pp. 248-256, 1958.

[42] L. J. DeGroot and J. Quintans, "The causes of autoimmune thyroid disease," Endocrine Reviews, vol. 10, no. 4, pp. 537$562,1989$.

[43] Y. Tomer and T. F. Davies, "Searching for the autoimmune thyroid disease susceptibility genes: from gene mapping to gene function," Endocrine Reviews, vol. 24, no. 5, pp. 694-717, 2003.

[44] A. Carlé, P. Laurberg, I. B. Pedersen et al., "Epidemiology of subtypes of hypothyroidism in Denmark," European Journal of Endocrinology, vol. 154, no. 1, pp. 21-28, 2006.

[45] G. B. Vanderver, A. Engel, and S. Lamm, "Cigarette smoking and iodine as hypothyroxinemic stressors in U.S. women of childbearing age: a NHANES III analysis," Thyroid, vol. 17, no. 8, pp. 741-746, 2007.

[46] G. E. Krassas and W. Wiersinga, "Smoking and autoimmune thyroid disease: the plot thickens," European Journal of Endocrinology, vol. 154, no. 6, pp. 777-780, 2006.

[47] A. P. Weetman, "Autoimmune thyroid disease," Autoimmunity, vol. 37, no. 4, pp. 337-340, 2004.

[48] T. F. Davies and N. Amino, "A new classification for human autoimmune thyroid disease," Thyroid, vol. 3, no. 4, pp. 331$333,1993$.

[49] F. Delange, B. de Benoist, E. Pretell, and J. T. Dunn, "Iodine deficiency in the world: where do we stand at the turn of the century?" Thyroid, vol. 11, no. 5, pp. 437-447, 2001.

[50] S. LaFranchi, "Congenital hypothyroidism: etiologies, diagnosis, and management," Thyroid, vol. 9, no. 7, pp. 735-740, 1999.

[51] C. G. P. Roberts and P. W. Ladenson, "Hypothyroidism," The Lancet, vol. 363, no. 9411, pp. 793-803, 2004.

[52] R. McCarrison, "Observations on endemic cretinism in the Chitral and Gilgit Valleys," The Lancet, vol. 172, no. 4444, pp. 1275-1280, 1908.

[53] O. D. Pharoah and K. J. Connolly, "A controlled trial of iodinated oil for the prevention of endemic cretinism: a longterm follow-up," International Journal of Epidemiology, vol. 16, no. 1 , pp. $68-73,1989$. 
[54] J. B. Vanderpas, M. T. Rivera-Vanderpas, P. Bourdoux et al., "Reversibility of severe hypothyroidism with supplementary iodine in patients with endemic cretinism," The New England Journal of Medicine, vol. 315, pp. 791-795, 1986.

[55] S. C. Boyages and J.-P. Halpern, "Endemic cretinism: toward a unifying hypothesis," Thyroid, vol. 3, no. 1, pp. 59-69, 1993.

[56] M. B. Zimmermann, "Research on iodine deficiency and goiter in the 19th and early 20th centuries," Journal of Nutrition, vol. 138, no. 11, pp. 2060-2063, 2008.

[57] Report of a committee of the Clinical Society of London to investigate the subject of myxoedema, Longmans, Green \& Co, London, UK, 1888.

[58] M. Schiff, "Bericht über eine Versuchsreihe betreffend die Wirkungen der Exstirpation der Schilddrüse," Archiv für Experimentelle Pathologie und Pharmakologie, vol. 18, no. 1-2, pp. 25-34, 1884.

[59] A. F. Eiselberg, "Ueber erfolgreiche Einheilung der Katzenschilddruse in die Bauchdecke und Auftreten von Tetanie nach deren Exstirpation," Wiener Klinische Wochenschrift, vol. 5, pp. 81-85, 1892.

[60] G. Eknoyan, "A history of the parathyroid glands," American Journal of Kidney Diseases, vol. 26, no. 5, pp. 801-807, 1995.

[61] A. M. Bettencourt and J. A. Serrano, "Un cas de myxedème traité par la greffe hypodermique du corps thyroïde d'un mouton," La Semana Medica, vol. 10, pp. 294-294, 1890.

[62] M. Borell, "Organotherapy, British physiology, and discovery of the internal secretions," Journal of the History of Biology, vol. 9, no. 2, pp. 235-268, 1976.

[63] G. R. Murray, "Note on the treatment of myxoedema by hypodermic injections of an extract of the thyroid gland of a sheep," British Medical Journal, vol. 2, pp. 796-797, 1891.

[64] G. R. Murray, "The life-history of the first case of myxoedema treated by thyroid extract," British Medical Journal, vol. 1, pp. 359-360, 1920.

[65] H. W. G. Mackenzie, "A case of myxoedema treated with great benefit by feeding with fresh thyroid glands," British Medical Journal, vol. 2, pp. 940-941, 1892.

[66] E. L. Fox, "A case of myxoedema treated by taking extract of thyroid by the mouth," British Medical Journal, vol. 2, p. 941, 1892.

[67] F. Vermeulen, "The treatment of myxoedema by feeding with thyroid glands," British Medical Journal, vol. 1, p. 266, 1893.

[68] E. H. Fenwick, "The diuretic action of fresh thyroid juice," British Medical Journal, vol. 2, p. 798, 1891.

[69] D. Marine, "On the occurrence and physiological nature of glandular hyperplasia of the thyroid (dog and sheep), together with remarks on important clinical, (human) problems," Bulletin of the Johns Hopkins Hospital, vol. 18, pp. 359-364, 1907.

[70] A. Magnus-Levy, "Ueber den respiratorischen Gaswechsel unter Einfluss der Thyroidea sowie unter verschiedenen pathologische Zustand," Berliner Klinische Wochenschrift, vol. 32, pp. 650-652, 1895.

[71] M. S. T. Logan and J. S. Logan, "The treatment of myxoedema with raw sheep thyroid gland and its introduction into practice in County Londonderry in 1892," Ulster Medical Journal, vol. 61, no. 1, pp. 86-93, 1992.

[72] G. R. Murray, "After-history of the first case of myxoedema cured by thyroid extract," British Medical Journal, vol. 1, pp. 334-335, 1896.

[73] F. C. Kendall, "The isolation in crystalline form of the compound containing iodin, which occurs in the thyroid," Journal of the American Medical Association, vol. 64, pp. 20422043, 1915.
[74] E. C. Kendall, "Reminiscences on the isolation of of thyroxine," Mayo Clinic Proceedings, vol. 39, pp. 548-552, 1964.

[75] C. R. Harington and G. Barger, "Thyroxine III: constitution and synthesis of thyroxine," Biochemical Journal, vol. 21, pp. 169-183, 1927.

[76] J. Gross and R. Pitt-Rivers, “The identification of 3:5:3'-Ltriiodothyronine in human plasma," The Lancet, vol. 259, no. 6705, pp. 439-441, 1952.

[77] J. Roche, S. Lissitsky, and R. Michel, "Sur la triiodothyronine, produit intermédiaire de la transformation de la diiodothyronine en thyroxine," Comptes Rendus Hebdomadaires des Séances de l'Academie des Sciences, vol. 234, pp. 997-999, 1952.

[78] J. Roche, S. Lissitsky, and R. Michel, "Sur la presence de triiodothyronine dans la thyroglobuline," Comptes Rendus Hebdomadaires des Séances de l'Academie des Sciences, vol. 234, pp. 1228-1230, 1952.

[79] F. D. Hart and N. F. Maclagan, "Oral thyroxine in treatment of myxoedma," British Medical Journal, vol. 1, pp. 512-518, 1950.

[80] W. Van't Hoff, G. M. Besser, R. Hoffenberg et al., "Thyroid extract," British Medical Journal, vol. 2, p. 200, 1978.

[81] S. S. Rengachary, C. Colen, and M. Guthikonda, "CharlesEdourd Brown-Sequard: an eccentric genius," Neurosurgery, vol. 62, no. 4, pp. 954-964, 2008.

[82] C. É. Brown-Séquard, "Des effets produits chez I'homme par des injections souscutanes d'un liquide retiré des testicules frais de cobaye et de chien," Comptes Rendus des Séances de la Societe de Biologie et de ses Filiales, vol. 1, pp. 415-419, 1889.

[83] C. É. Brown-Séquard, "Remarques sur les effets produits sur la femme par des injections sous-cutanes d'un liquide retiré d'ovaires d'animaux," Archives de Physiologie Normale et Pathologique, vol. 2, pp. 456-457, 1890.

[84] G. Vassale, "Intorno agli effetti dell' injezione intravenosa di succo di tiroide nei cani operati di estirpazione della tiroide," Revista Sperimentale di Freniatria e di Medicina Legale, vol. 16, pp. 439-455, 1890, (Summary in Zentralbl med Wissensch $1891 ; 28: 14)$.

[85] E. Gley, "Note preliminaire sur les effets physiologiques du suc extrait de la glande thyroide," Comptes Rendus des Séances de la Societe de Biologie et de ses Filiales, vol. 3, pp. 250-251, 1891.

[86] W. G. MacCallum and C. Voegtlin, "On the relation of tetany to the parathyroid glands and to calcium metabolism," Journal of Experimental Medicine, vol. 11, pp. 118-151, 1909.

[87] R. van der Velden, "Die Nierenwirkung von Hypophysenextrakten beim Menschen," Berliner Klinische Wochenschrift, vol. 50, pp. 2083-2086, 1913.

[88] F. Farini, "Diabete insipido ed opoterapia ipofisaria," Gazzetta Degli Ospedali e delle Cliniche, vol. 34, pp. 1135-1139, 1913.

[89] R. Tattersall, "Pancreatic organotherapy for diabetes, 18891921," Medical History, vol. 39, no. 3, pp. 288-316, 1995.

[90] P. W. Williams, "Lecture at the sixty-second Annual Meeting of the British Medical Association: notes on diabetes treated with extract and by grafts of sheep's pancreas," British Medical Journal, vol. 2, pp. 1303-1304, 1894.

[91] D. Conan, Sherlock Holmes: The Complete Illustrated Short Stories, Chancellor Press, London, UK, 1985.

[92] C. K. Tam, "'Shotgun therapy': the understanding and use of thyroid organotherapy in Britain, 1890-1925," Pharmaceutical Historian, vol. 37, no. 4, pp. 50-56, 2007.

[93] D. Marine, "Iodine in the treatment of disease of the thyroid gland," Transactions of the American Clinical and Climatological Association, vol. 41, pp. 38-52, 1925.

[94] P. Laurberg, "Editorial: iodine intake-what are we aiming at?" Journal of Clinical Endocrinology and Metabolism, vol. 79, no. 1, pp. 17-19, 1994. 


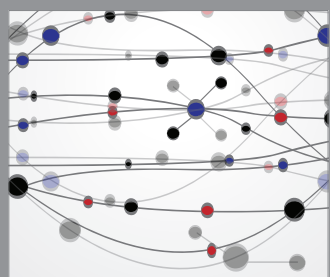

The Scientific World Journal
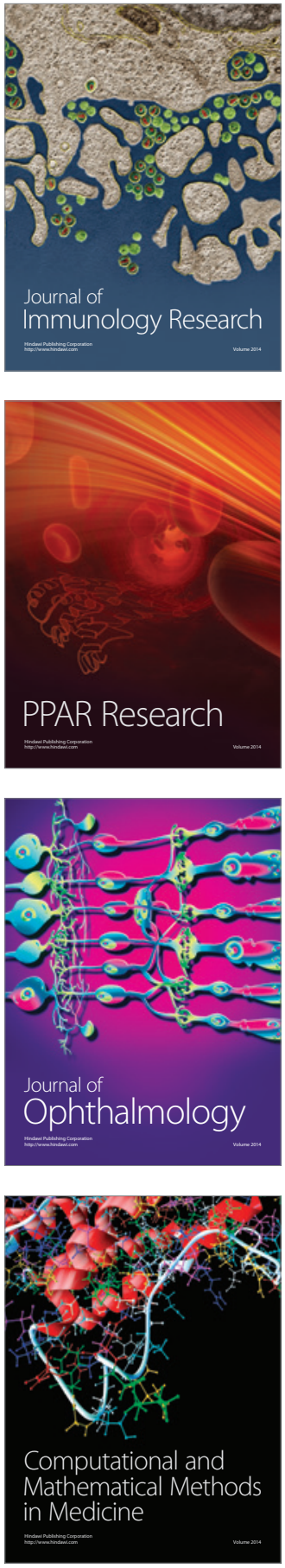

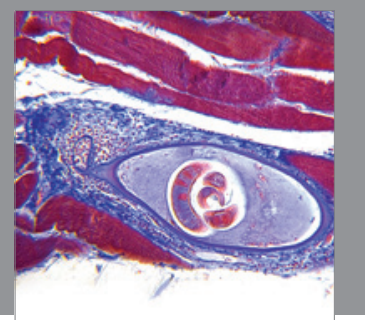

Gastroenterology

Research and Practice
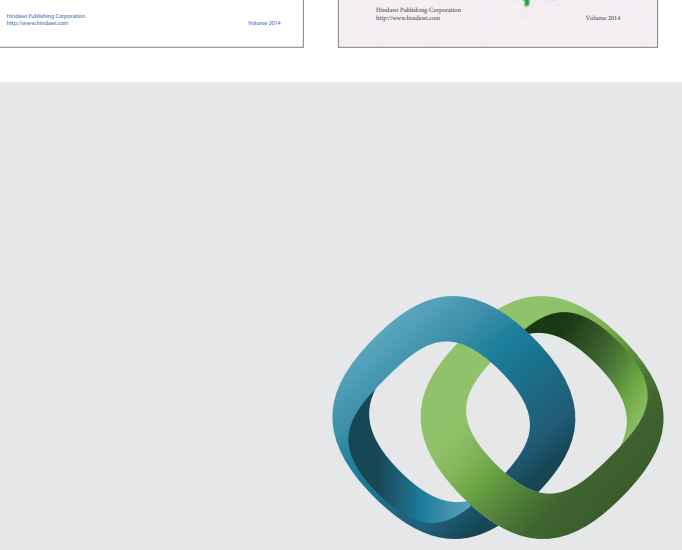

\section{Hindawi}

Submit your manuscripts at

http://www.hindawi.com
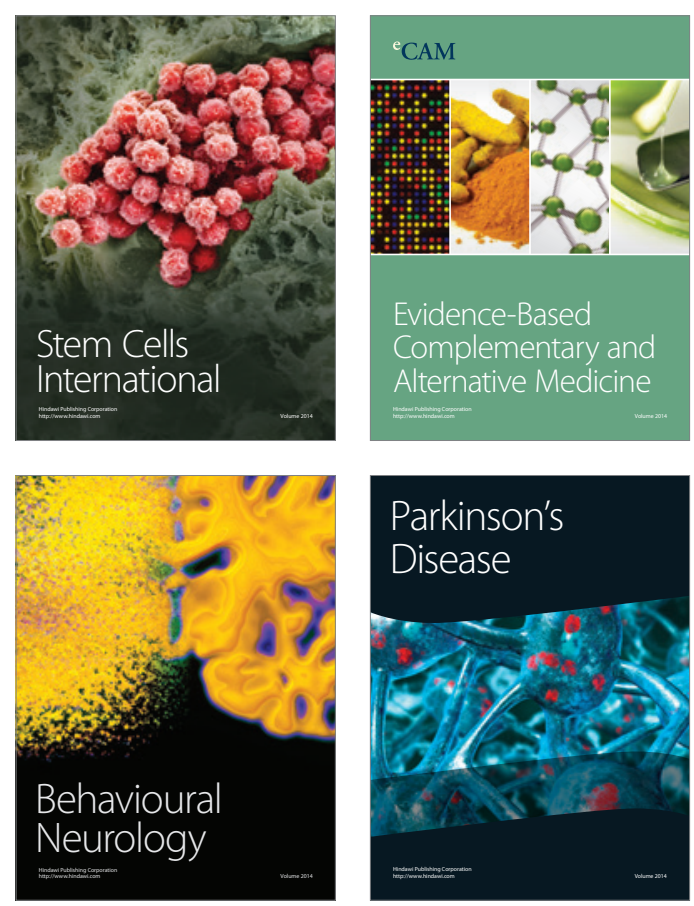

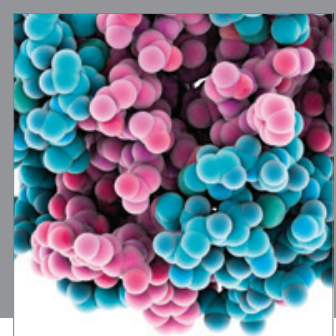

Journal of
Diabetes Research

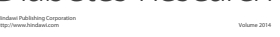

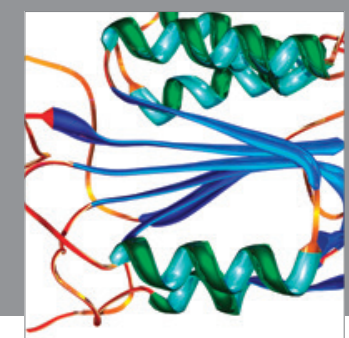

Disease Markers
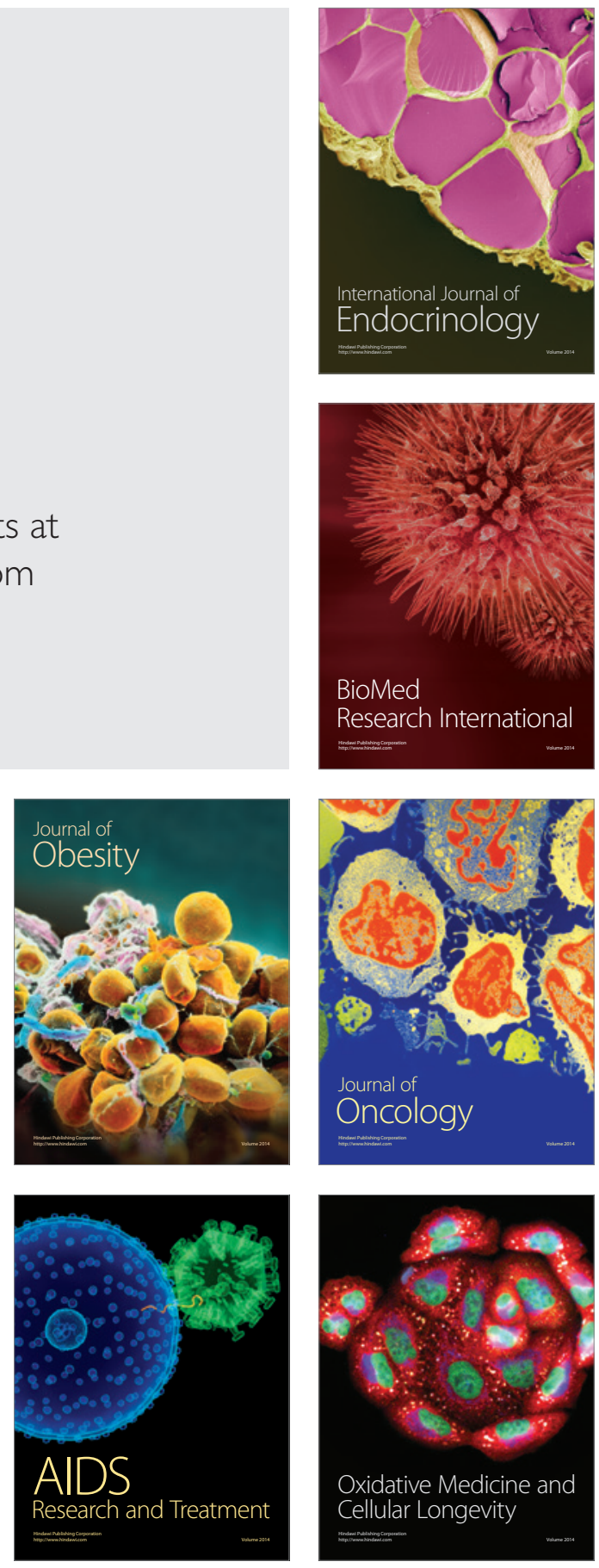